\title{
Translation and adaptation of the Pediatric Cardiac Qual- ity of Life Inventory to the Portuguese population
}

Tradução e adaptação do Pediatric Cardiac Quality of Life Inventory para a população portuguesa

Traducción y adaptación del Pediatric Cardiac Quality of Life Inventory para la población

Sandra Ilda Morais Lopes* (D); Jorge Manuel Amado Apóstolo** (D); Tiago João Simóes Flórido*** (D)

\begin{abstract}
Background: Congenital heart diseases have a high prevalence in Portugal in the pediatric age. Understanding the quality of life of children with congenital heart diseases will allow to know its impact and the adaptive process involved. We lack, however, measurement instruments adapted to the Portuguese population.

Objective: Translate and adapt the Pediatric Cardiac Quality of Life Inventory (PCQLI) for the Portuguese population. Methodology: The original questionnaire was translated according to international recommendations. The final version of the instrument was applied in a non-probability sample comprised 59 children, 80 adolescents and their parents, totaling 278 respondents. The facial validity analysis was performed with the pre-test and internal consistency analysis using Cronbach's Alpha.

Results: In the pre-test it was verified that the items are comprehensible, useful with a simple and colloquial language. The internal consistency for the total score varied for the different versions between 0.834 and 0.932 .

Conclusion: The Portuguese version of PCQLI allowed us to evaluate the quality of life of children with congenital heart disease in a satisfactory way. However, a larger sample is needed to develop the validation process.
\end{abstract}

Keywords: quality of life; congenital heart disease; child; adolescent

\section{Resumo}

Enquadramento: As cardiopatias congénitas têm uma elevada prevalência em Portugal na idade pediátrica. Analisar a qualidade de vida destas crianças permitirá conhecer o impacto da doença e os processos adaptativos envolvidos. Carece-se, no entanto, de instrumentos de mensuração adaptados à população portuguesa.

Objetivo: Traduzir e adaptar o Pediatric Cardiac Quality of Life Inventory (PCQLI) para a população portuguesa. Metodologia: $\mathrm{O}$ questionário original foi traduzido segundo recomendaçóes internacionais. A versão final do instrumento foi aplicada numa amostra não probabilística, de 59 crianças, 80 adolescentes e respetivos pais totalizando 278 respondentes. Realizou-se a análise da validade facial aplicando um pré-teste, e a análise da consistência interna recorrendo ao alfa de Cronbach.

Resultados: No pré-teste constatou-se que os itens são compreensíveis, úteis e de fácil resposta, com uma linguagem simples e coloquial. A consistência interna para o score total variou para as diferentes versóes entre 0,834 e 0,932.

Conclusáo: A versão portuguesa do PCQLI permitiu avaliar a qualidade de vida das crianças com cardiopatia congénita de forma satisfatória. Contudo, será necessária uma amostra maior para desenvolver o processo de validaçáo.

Palavras-chave: qualidade de vida; doença cardíaca congénita; criança; adolescente

*MSc., RN, Coimbra University and Hospital Center, 3030-093, Coimbra, Portugal [sandrailda@esenfc.pt].0 https://orcid.org/0000-0002-0421-7261. Contribution to the article: literature search, data collection, analysis and discussion, and article writing. Address

cle: literature search, data collection, analysis and discussion, and article writing. Address
for correspondence: Rua da Misericórdia, n. 47 - R/C Esq., 3030-093, Coimbra.
**Ph.D., Professor. Nursing School of Coimbra, 3046-851, Coimbra, Portugal [japosto*: Ph.D., Professor, Nursing School of Coimbra, 3046-851, Coimbra, Portugal [japostolo@esenfc.pt].0 https://orcid.org/0000-0003-2205-8409. Contribution to the artict
literature search, statistical data treatment, discussion, and final article revision. ***MSc., RN, Regional Health Administration-Center, UCC Coimbra Saúde, 3030-093, * *MSc., RN, Regional Health Administration-Center, UCC Coimbra Saúde, 3030-093 Contribution to the article: literature search, statistical data treatment, and data analysis.

\section{Resumen}

Marco contextual: Las cardiopatías congénitas tienen una alta prevalencia en Portugal en la edad pediátrica. Analizar la calidad de vida de estos nińos permitirá conocer el impacto de la enfermedad y los procesos adaptativos involucrados. Nos faltan, sin embargo, los instrumentos de medición adaptados a la población portuguesa.

Objetivo: Traducir y adaptar el Pediatric Cardiac Quality of Life Inventory (PCQLI) para la población portuguesa.

Metodología: El cuestionario original se tradujo según las recomendaciones internacionales. La versión final del instrumento se aplicó en una muestra no probabilística, de 59 niños, 80 adolescentes y los respectivos padres, lo cual forma un total de 278 encuestados. Se realizó el análisis de la validez facial aplicando un pretest y un análisis de la consistencia interna, para lo cual se recurrió al alfa de Cronbach.

Resultados: En el pretest se constató que los ítems son comprensibles, útiles y de fácil respuesta, con un lenguaje simple y coloquial. La consistencia interna para la puntuación total varía para las diferentes versiones entre 0,834 y 0,932 .

Conclusión: La versión portuguesa del PCQLI permite evaluar la calidad de vida de los niños con cardiopatía congénita de manera satisfactoria. Sin embargo, se necesita una muestra más grande para desarrollar el proceso de validación.

Palabras clave: calidad de vida; enfermedad cardíaca congénita; niño; adolescente

Received for publication: 03.04 .18

Accepted for publication: 23.07 .18 


\section{Introduction}

Congenital heart disease (CHD) is one of the most prevalent congenital diseases in Portugal, with an incidence of 6 to 8 per 1,000 live births (Kaku, 2018).

Over the past decades, several factors have contributed to significantly reduce the morbidity and mortality rates of children with heart disease and, consequently, increase their life expectancy. Thus, a growing number of patients with CHD reach adolescence and adulthood. However, the literature on comorbidities associated with chronic diseases in children and adolescents is scarce.

Quality of life has been difficult to define due to its complexity, comprehensiveness, and multidimensionality. According to the World Health Organization (WHO, 2014), quality of life is defined as an individual's perception of their position in life in relation to their goals, expectations, and concerns. Therefore, in addition to the complexity of defining this concept, it is also difficult to conduct studies which provide a comprehensive knowledge of the reality experienced by each child, adolescent or parent, in various contexts and stages of their life cycle. The perception of quality of life varies from person to person, across families. For this reason, it is important to assess the personal perspective of each child or adolescent and their parents (Marino, Cassedy, Drotar, \& Wray, 2016; Niemitz et al., 2017). The analysis of the characteristics of the quality of life of children/adolescents with CHD is of undeniable interest because it will allow identifying the impact of the disease and/ or treatments and better understanding patients, their evolution, and adaptation to the disease. In addition, it will improve the communication between patients, parents, and health care providers, the definition of priorities based on patients' preferences, the monitoring of changes over time or in response to specific therapeutic strategies, the detection of other medical or psychosocial problems, the identification of risk factors for low quality of life, the implementation of a family-centered care philosophy, the promotion of adherence to treatment, and the satisfaction of the patient and the family (Marino et al., 2010; Marino et al. 2016).

Given the lack of instruments in European Portuguese for assessing the quality of life of children and adolescents with CHD, a literature review was performed to identify scales in other languages that could be used in this research. After a detailed analysis of these scales, the Pediatric Cardiac Quality of Life Inventory (PCQLI) by Marino et al. (2008) was selected. Permission was obtained for its use. Thus, the objective of this study was to translate and adapt the PCQLI to the Portuguese culture.

\section{Background}

CHD is the most common birth defect. According to Muner-Hernando, Gil-Mira, and Zapardiel (2013), it represents $46 \%$ of neonatal deaths and is associated with moderate diseases in the long-term. Today, more than $90 \%$ of newborns with a diagnosis of CHD reach adult life (Daudt \& Zielinsky, 2013).

Survival rates vary by disease complexity: long-term survival ( $>20$ years) rates for children with simple CHD are estimated to be 95\%, 90\% for moderate CHD, and $80 \%$ for severe CHD (Marino et al., 2012).

CHD is defined as a structural or functional abnormality of the heart or great vessels that occurs during the fetal period (Setty et al., 2017). CHD can be asymptomatic, where the child has a normal development and lifestyle, or symptomatic, conditioning the child's dayto-day life and causing delayed psychomotor development (Marino et al., 2016).

The type of treatment depends on the type and severity of the heart disease, the presence and severity of symptoms, and the potential to determine reversible secondary changes. Thus, it can be a conservative or surgical treatment (Setty et al., 2017).

In the last decades, several factors have contributed to significantly reduce the morbidity and mortality rates of children with heart disease. Simultaneously, there was an increase in the life expectancy of this population with significant disease-related physical, psychosocial, and neurodevelopmental comorbidities which have an impact on their quality of life (Marino et al., 2012; Niemitz et al., 2017).

Chronic diseases are becoming increasingly common in child health. These conditions affect children's development, as well as their relationship with the environment and those surrounding them. According to Sousa and Cruz (2009), they are characterized by their duration, their long treatments and hospital readmissions, and their impact on children and their parents and on functions and emotions.

However, some factors inherent to the pediatric age can limit the assessment of health-related quality of life, such as age range, devel- 
opmental stage, and diversity of anomalies, therapies (medical or surgical), and outcomes (Marino et al., 2012).

Parents' perspective should be taken into account in the case of smaller children due to their age and lack of cognitive and linguistic skills to interpret data collection tools (Rajmil, López, López-Aguilà, \& Alonso, 2013). In addition, Marino et al. (2016) share the opinion that it is essential to understand the perceptions of quality of life of children/adolescents and their parents. These views will contribute to developing a care plan directed at/focused on the needs of children and families, prioritizing problems, facilitating communication, detecting potential problems, identifying preferences, and monitoring the patient's evolution and response to treatment. In clinical practice, the integration of different points of view improves quality of life assessment; the perceptions of children/adolescents and their parents should complement each other (Niemitz et al., 2017).

At an initial stage of this study, a literature review revealed the opinion of several authors about the key characteristics of a quality of life assessment tool. After a detailed analysis of the instruments used for assessing the quality of life of children and adolescents with heart disease, the PCQLI was selected. The PCQLI includes a questionnaire consisting of items rated on a Likert-type scale with versions for children aged 8 to 12 years, adolescents aged 13 to 18 years, and their parents. Its original version is written in English (American English), so it was translated into Portuguese according to international guidelines (DISABKIDS, 2004).

\section{Research question}

Is the Portuguese version of the Pediatric Cardiac Quality of Life Inventory a reliable tool for assessing the perceived quality of life in a sample of children and adolescents with CHD and their parents living in a center region of Portugal?

\section{Methodology}

This study consisted in the process of translation and cultural adaptation of the PCQLI to the Portuguese population.

The target population was composed of children aged 8 to 12 years $(n=59)$ and adolescents aged 13 to 18 years $(n=80)$ with CHD, as well as their parents (59 parents of children and 80 parents of adolescents). These children and adolescents attended the outpatient cardiology consultation of a pediatric hospital in the central region of Portugal, mastered the Portuguese language, and had no psychomotor problems. The following exclusion criteria were applied: children/adolescents with delayed psychomotor development; children/ adolescents and their parents who did not master the Portuguese language; children/ adolescents who had undergone surgery for less than 6 months; children aged less than 8 years. The minimum age for data collection was 8 years old because the original tool is validated for children above 8 years of age who are already capable of answering a written questionnaire. The maximum age was 18 years old because that is the age limit for receiving pediatric care and marks the transition to adulthood.

The criterion of children and adolescents with congenital heart disease was established because CHD is one of the most prevalent congenital diseases. Therefore, this study aimed to analyze its impact on these children and adolescents throughout their life-cycle. Moreover, this study aimed to understand the parents' perceptions about their children's quality of life.

The sample was composed of all individuals who met the inclusion criteria and showed interest in participating in the study, and who, after being explained the research objectives and project, agreed to participate on a voluntary basis by giving their written permission for data collection according to the planned methodology.

The nonprobability consecutive sampling method was used. For reasons of accessibility and convenience, the sample was composed of children and adolescents with CHD who attended the cardiology consultation of a pediatric hospital in the central region on Mondays and Thursdays between February and July 2014.

The questionnaire for children, adolescents, and parents included questions on the sociodemographic (age, gender, nationality) and academic characteristics (grade and academic performance addressed in the question on school retention) and the PCQLI. This instrument includes a general question and the questionnaire. First, it includes the following general health perception question, which is a distinct question regarding overall health status and general quality of life: "In general, would you say your health is...". It is rated 
on a 5-point Likert-type scale: excellent (1), very good (2), good (3), fair (4), and poor (5). The scores of this question are not included in the total score of the questionnaire (Marino, Hottinger, Drotar, Wray, \& Ittenbach, 2014). The questionnaire is composed of a set of statements included in the PCQLI which are referred to as items. These items are grouped into dimensions, with each of them being composed of items rated on a 5-point Likerttype scale from strongly agree (1) to strongly disagree (5). Each subscale/dimension represents the patients' perceptions of the impact of the heart disease on distinct areas: Disease impact is associated with the physical func- tion and Psychosocial impact is associated with the psychological and social function (Marino et al., 2014).

Thus, the PCQLI has four forms: child (aged 8 to 12 years), parent of child, adolescent (aged 13 to 18 years), and parent of adolescent. The child form consists of 23 items: 14 in the Disease impact subscale and nine in the Psychosocial impact subscale. The adolescent form is composed of 17 items in the Disease impact subscale and 12 items in the Psychosocial impact subscale.

The PCQLI generates three scores: Disease impact subscale score, Psychosocial impact subscale score, and Total score (Table 1).

Table 1

Distribution of PCQLI items by subscale

\begin{tabular}{lll}
\hline Form & Subscale & Items \\
\hline \multirow{2}{*}{ Child or Parent of child } & Disease impact & $1-7 ; 9 ; 10 ; 12 ; 14 ; 18-20$ \\
\cline { 2 - 3 } & Psychosocial impact & $8 ; 11 ; 13 ; 15-17 ; 21-23$ \\
\hline \multirow{2}{*}{ Adolescent or Parent of adolescent } & Disease impact & $2-6 ; 8-12 ; 14 ; 15 ; 17-21$ \\
\cline { 2 - 3 } & Psychosocial impact & $1 ; 7 ; 13 ; 16 ; 22-29$ \\
\hline
\end{tabular}

The Disease impact and Psychosocial impact subscale scores are calculated individually based on the following formula:

$$
\frac{\sum \text { subscale item response values }- \text { No. of subscale items }}{4 \times \text { No. of subscale items }} \times 50
$$

The Total score is calculated from the Disease Impact and Psychosocial Impact subscales using the following formula:

Disease impact subscale score + Psychosocial impact subscale score

As the sum of these two subscale scores, the total score has a maximum of 100 points (the higher the score, the higher the level of perceived quality of life).

After evaluating the importance of the PCQLI items, the associated concepts and their relevance to the target population through the literature review, the instrument was translated and culturally adapted to the Portuguese population according to the guidelines recommended by Vilelas (2009). The following steps were followed: (1) Initial translation - two bilingual translators performed an independent translation of the original version of the PCQLI from American English into
Portuguese; (2) Synthesis of both translations - both translations were compared by the principal investigator, who identified some differences between them. These differences were analyzed and discussed by a group of experts, who selected words that were more simple and easier to understand, and the first consensus version of the PCQLI in Portuguese was obtained; (3) Translation - the consensus version in Portuguese was back-translated into American English by another translator. The obtained PCQLI versions and the original instruments were analyzed and compared. Given the simplicity of the instrument and the clarity of the statements, there 
was a high semantic, cultural, and idiomatic concordance. The few divergent questions were discussed and, after a consensus, the second Portuguese version of the PCQLI was obtained; (4) Revision by the group of experts - the Portuguese version of the PCQLI was revised by two specialist nurses in child health and pediatrics with over 7 years of profession- al experience, as well as by a different translator from those in the previous steps, who compared the items and analyzed their level of agreement with the original English versions. At the end of this meeting, this version (Tables 2 and 3) was considered to be well translated, accurate, easy-to-understand, and written in a clear language.

\section{Table 2}

Consensus version of the PCQLI for children and their parents

\begin{tabular}{|c|c|}
\hline Child version & Parent of child version \\
\hline Devido ao meu problema do coração... & Devido ao problema de coraçáo do seu filho... \\
\hline 1. Tomo demasiados medicamentos & 1. Ele(a) toma demasiados medicamentos \\
\hline 2. Recebo um tratamento especial & 2. Ele(a) recebe um tratamento especial \\
\hline 3. Falto muito à escola & 3. Ele(a) falta muito à escola \\
\hline 4. Os adultos à minha volta são demasiado protetores & 4. Os adultos à volta dele(a) são demasiado protetores \\
\hline 5. As outras pessoas tratam-me de forma diferente & 5. As outras pessoas tratam-no(a) de forma diferente \\
\hline 6. Não posso fazer as atividades físicas que quero fazer & 6. Ele(a) não pode fazer as atividades físicas que quer fazer \\
\hline 7. Pareço diferente de toda a gente no mau sentido & 7. Ele(a) parece diferente de toda a gente no mau sentido \\
\hline 8. Tenho medo de procedimentos médicos & 8. Ele(a) tem medo de procedimentos médicos \\
\hline 9. Recebo demasiada atenção & 9. Ele(a) recebe demasiada atenção \\
\hline 10. Canso-me facilmente & 10. Ele(a) cansa-se facilmente \\
\hline 11. Não posso comer ou beber o que quero & 11. Ele(a) não pode comer ou beber aquilo que quer \\
\hline 12. Sinto falta de atividades sociais & 12. Ele(a) sente falta de atividades sociais \\
\hline 13. Sinto-me diferente de toda a gente no mau sentido & 13. Ele(a) sente-se diferente de toda a gente no mau sentido \\
\hline 14. Vou a demasiadas consultas médicas & 14. Ele(a) vai a demasiadas consultas médicas \\
\hline 15. Sinto-me mal pelos meus pais & 15. Ele(a) sente-se mal pelos pais \\
\hline 16. Tenho medo de morrer & 16. Ele(a) tem medo de morrer \\
\hline 17. Tenho dificuldade em fazer amigos & 17. Ele(a) tem dificuldade em fazer amigos \\
\hline $\begin{array}{l}\text { 18. Tomo medicamentos que causam efeitos secundá- } \\
\text { rios negativos }\end{array}$ & $\begin{array}{l}\text { 18. Ele(a) toma medicamentos que lhe causam efeitos } \\
\text { secundários negativos }\end{array}$ \\
\hline 19. O trabalho escolar é difícil para mim & 19. O trabalho escolar é difícil para ele(a) \\
\hline $\begin{array}{l}\text { 20. Tenho de me conter quando estou a fazer atividades } \\
\text { físicas }\end{array}$ & $\begin{array}{l}\text { 20. Ele(a) tem de se conter quando está a fazer atividades } \\
\text { físicas }\end{array}$ \\
\hline 21. Sinto que a vida é injusta & 21. Ele(a) sente que a vida é injusta \\
\hline 22. Preocupo-me muitas vezes com o meu futuro & 22. Ele(a) preocupa-se muitas vezes com o seu futuro \\
\hline 23. As outras pessoas gozam comigo & 23. As outras pessoas gozam com ele \\
\hline
\end{tabular}


Table 3

Consensus version of the PCQLI for adolescents and their parents

\section{Adolescent version}

Devido ao meu problema do coração...

1. Sinto-me diferente de toda a gente no mau sentido

3. Falto muito à escola
4. Sinto-me culpado(a) pelo stress que a minha doença
do coração causa à minha família

\begin{tabular}{l} 
5. O trabalho escolar é difícil para mim \\
\hline 6. Recebo demasiada atençáo \\
\hline 7. Tenho medo de procedimentos médicos \\
\hline 8. Canso-me facilmente \\
\hline 9. Tomo demasiados medicamentos \\
10. Os adultos à minha volta são demasiado protetores \\
11. Sinto-me sem energia \\
12. Tenho de me conter quando estou a fazer atividades \\
físicas
\end{tabular}

2. Não posso fazer as atividades físicas que quero fazer

\section{Parent of adolescent version}

Devido ao problema de coração do seu filho...

1. Ele(a) sente-se diferente de toda a gente no mau sentido

2. Ele(a) não pode fazer as atividades físicas que quer fazer

3. Ele(a) falta muito à escola

4. Ele(a) sente-se culpado(a) pelo stress que a sua doença do coração causa à família

5. O trabalho escolar é difícil para ele(a)

6. Ele(a) recebe demasiada atenção

7. Ele(a) tem medo de procedimentos médicos

8. Ele(a) cansa-se facilmente

9. Ele(a) toma demasiados medicamentos

10. Os adultos à volta dele são demasiado protetores

11. Ele(a) sente-se sem energia

12. Ele(a) tem de se conter quando está a fazer atividades físicas

13. As outras pessoas sentem-se desconfortáveis perto dele

14. Estou a sofrer 14. Ele(a) está a sofrer

15. É provável que venha a ter outros problemas de saúde

15. É provável que ele(a) venha a ter outros problemas de saúde

16. Não posso vestir/usar o que quero (roupas, piercings, tatuagens)

16. Ele(a) não pode vestir/usar o que quer (roupas, piercings, tatuagens)

17. Passo demasiado tempo a cuidar da minha saúde

17. Ele(a) passa demasiado tempo a cuidar da sua saúde

18. Tomo medicamentos que me causam efeitos secundários negativos

18. Ele(a) toma medicamentos que causam efeitos secundários negativos

\begin{tabular}{ll}
\hline 19. É provável que o meu estado de saúde piore & 19. É provável que o seu estado de saúde piore \\
\hline 20. Recebo um tratamento especial & 20. Ele(a) recebe um tratamento especial \\
\hline 21. Sinto falta de atividades sociais & 21. Ele(a) sente falta de atividades sociais \\
\hline 22. Sou autodestrutivo(a) & 22. Ele(a) é autodestrutivo(a) \\
\hline 23. Tenho medo de morrer & 23. Ele(a) tem medo de morrer \\
\hline 24. É difícil deslocar-me de um local para outro & 24. É difícil para ele(a) deslocar-se de um local para outro \\
\hline 25. Sinto-me zangado & 25. Ele(a) sente-se zangado \\
\hline 26. As outras pessoas tratam-me de maneira diferente & 26. Há pessoas que o(a) tratam de maneira diferente \\
\hline 27. Pareço diferente de toda a gente no mau sentido & $\begin{array}{l}\text { 27. Ele(a) parece diferente de toda a gente no mau } \\
\text { sentido }\end{array}$ \\
\hline 28. Preocupo-me com o meu futuro & 28. Ele(a) preocupa-se com o seu futuro \\
\hline 29. Sinto-me impotente & 29. Ele(a) sente-se impotente
\end{tabular}


Subsequently, the questionnaire was applied in a pre-test and informal interviews were performed with 10 children/adolescents and their parents.

After the steps of translation and face validity analysis, the internal consistency of the Portuguese version of the PCQLI was assessed in a clinical setting.

Duly completed questionnaires were considered valid for this study.

Data were collected with the collaboration of the nursing team of the cardiology consultation. At this consultation, which occurred before the researcher's contact with the families, they were informed that they would be contacted to participate in the study. The questionnaires were applied by the researcher between the nursing consultation and the medical consultation. The respondents were supervised while completing the questionnaires to clarify any doubts and avoid contamination of results if children and parents shared ideas. It should be noted that there was a previous contact with the nurses working in that unit with the purpose of identifying the children who met the inclusion criteria.

The questionnaire was delivered in a sealed envelope. Each envelope had another two envelopes: one with the version for children/ adolescents and another one with the version for parents, duly identified on the front of the envelope, with the informed consent form attached to each questionnaire. All questionnaires were coded $s$ that each dyad could be identified later on while safeguarding privacy and anonymity.

Data were statistically analyzed using IBM SPSS Statistics for Windows, version 20.0.

The researchers complied with all ethical and legal aspects of scientific research. However, in order to meet the high levels of requirements and ethical responsibility, the researchers submitted the research design to the Ethics Committee of the Health Sciences Research Unit: Nursing, Nursing School of Coimbra (ESEnfC), and obtained a favorable opinion (No. 158-04/2013). Then, the authors asked permission from the authors of the original PCQLI version (Marino et al., 2008) to translate and validate the questionnaire to the Portuguese population, as well as permission to carry out the study from the director of the
Pediatric Intermediate Management Unit of the Coimbra Hospital and University Center (CHUC) and the director of the pediatric cardiology consultations. All participants signed an informed consent to participate in the study.

\section{Results}

The process of translation of the PCQLI into European Portuguese showed satisfactory results. The consensus version preserved the meaning of the original version of the PCQLI. The original version of the PCQLI was translated into Portuguese by two independent translators. Both translations were compared by the principal investigator, revealing some differences in some items. Thus, a consensus version was obtained which was analyzed by a group of experts for clarity of language and equivalence of the meaning of the translated items. At the meeting with the expert group, after a comparison of the first translations, the final Portuguese version was obtained - the consensus version. However, the experts raised some doubts concerning some items. In the item "I miss social activities", they had doubts between "sinto falta de atividades sociais" and "falto a atividades sociais" and, after discussion, they decided to translate it as "sinto falta de atividades sociais". The criterion "I hold back when I am doing physical activities" raised some doubts between the expression "Eu tenho de me conter" and "Retraio-me" and they decided to use "tenho de me conter quando estou a fazer atividades fisicas". In "other people tease me", doubts existed between "há pessoas que gozam comigo" and "os outros metem-se comigo", and they decided to use "as outras pessoas gozam comigo"." With regard to "I feel sluggish", they hesitated between "eu sinto-me sem energia" and "sinto-me lento", choosing the first possibility. In "I cannot wear what I want", the experts discussed between the option "não posso vestir o que quero" and "não posso usar o que quero", and decided to add more information to the item: "não posso vestir/usar o que quero (roupas, piercings, tatuagens,...)". Finally, in the item "I feel helpless", they had doubts between "sinto-me impotente" and "eu sinto-me desamparado(a)", but used the first option.

The final result of this meeting was the consen- 
sus version of the scale in Portuguese, which was back-translated into English to check for any differences in meaning and/or content between the original and the translated versions, thus ensuring the quality of the instrument to be used (Vilelas, 2009).

Then, the obtained PCQLI version and the original instrument were analyzed and compared to check for equivalence of meaning of the translated items. The differences related to the use of synonyms which did not alter the meaning of the sentences.

The final version in Portuguese was analyzed by a group of experts who compared the items and identified their level of agreement (regarding clarity, colloquial language, translation, understandability, and reading style) with the original English versions. The experts found that this version was well translated, accurate, easy to understand, and written in a clear language. Thus, the pre-test version of the PCQLI in Portuguese was obtained.

In the pre-test phase, the researcher established a personal contact with all participants to explain the study objective and analyze face validity. This sample was composed of 10 parents of children and adolescents, as well as five children and five adolescents. Overall, they had no difficulty in completing the questionnaire and all of them considered that the questions were clear, easy-to-understand, and colloquial.

Thus, the translation of this instrument was considered appropriate and the final versions of the PCQLI were obtained.

A total of 280 questionnaires were gathered (two pairs were excluded because the quality assessment scale was not duly completed in the parent version). Thus, a sample of 59 pairs of questionnaires of the child version and 80 pairs of questionnaires of the adolescent version were obtained, in a total of 278 respondents among children, adolescents, and parents.

The analysis of sample distribution by age showed that the mean age was 9.68 years in the group of children and 15.1 years in the group of adolescents. In relation to gender, there was a similar distribution, with a slight predominance of boys in the group of children (33; 55.93\%). In the group of adolescents, there were more boys $(55 ; 68.75 \%)$ than girls $(25 ; 31.25 \%)$.
As regards their academic characteristics, none of the children had a special education study plan. As for their academic performance, $13.56 \%$ of them had already failed at least one year. In this group of children attending $1^{\text {st }}$ to $7^{\text {th }}$ grade, most of them attended $5^{\text {th }}$ grade $(22.04 \%)$. In the group of adolescents, only three of them $(3.75 \%)$ had a special education study plan and $32.50 \%$ of them had failed at least one year. Most of them attended the $9^{\text {th }}$ grade $(25 \%)$ and the $10^{\text {th }}$ grade $(25 \%)$.

In relation to the degree of kinship of children/ adolescents' legal representative who completed the questionnaire, in the group of children, $77.97 \%$ of the questionnaires were filled out by the mothers, $20.34 \%$ by the fathers, and $1.69 \%$ by a grandfather. In the group of adolescents, $70 \%$ of the questionnaires were filled out by the mothers, $26.25 \%$ by the fathers, and $3.75 \%$ by uncles and grandparents.

The assessment of some of the psychometric properties of the Portuguese version of the scale showed a good internal consistency for the total score $\alpha=0.834$ and for the Disease impact subscale $\alpha=0.824$, as well as a reasonable consistency for the Psychosocial impact subscale $\alpha$ $=0.626$ in the group of children (Table 4). In the original version, these two subscales had $\alpha$ $=0.88$ and $\alpha=0.78$, respectively. Children's parents had higher internal consistency scores: total score $\alpha=0.894$; Disease impact subscale $\alpha=0.861$, and Psychosocial impact subscale $\alpha=0.795$ (in the original version, both subscales had a $\alpha=0.89$ and $\alpha=0.83$, respectively). In the group of adolescents, the total score showed a very good internal consistency $(\alpha=$ 0.932) and the Disease impact and Psychological impact subscales also had a high internal consistency ( $\alpha=0.892$ and $\alpha=0.851$, respectively); in the original scale, the scores for both subscales were similar $(\alpha=0.89$ and $\alpha=0.85$, respectively). With regard to adolescents' parents, the results were identical, with $\alpha=0.932$ for the total score; $\alpha=0.885$ for the Disease impact subscale; and $\alpha=0.882$ for the Psychosocial impact subscale. In the original scale, the internal consistency of both subscales was $\alpha=$ 0.91 and $\alpha=0.85$, respectively. Similar results were found in the original version in American English. 
Table 4

Results of the internal consistency for the subscales and total score of the Portuguese version of the PCQLI

\begin{tabular}{lcccc}
\hline \multirow{2}{*}{ Subscales } & \multicolumn{4}{c}{ Version } \\
\cline { 2 - 5 } & Child & Parent of child & Adolescent & Parent of adolescent \\
\hline Impact disease subscale & 0.824 & 0.861 & 0.892 & 0.885 \\
\hline Psychosocial impact subscale & 0.626 & 0.795 & 0.851 & 0.882 \\
\hline Total Score & 0.834 & 0.894 & 0.932 & 0.932 \\
\hline
\end{tabular}

In addition, Guttman's split-half coefficient was calculated and showed that, in the child version, the Disease impact and Psychological impact subscales showed values of 0.859 and 0.623 , respectively, which were similar values to those found in the parent of child version (0.883 and 0.724 respectively). In turn, values of 0.898 and 0.833 were found in the adolescent version for the Disease impact and Psychological impact subscales, respectively. In the parent of adolescent version, these values were 0.858 and 0.872 , respectively.

In the general health perception question of PCQLI, most of the children rated it as good (66.10\%), followed by very good (18.65\%) and fair $(15.25 \%)$. None of the children rated their health as excellent. Approximately half of the children's parents rated their children's health as good (50.85\%), 30.51\% as very good, $11.86 \%$ as fair, and $6.78 \%$ as excellent. In turn, in the group of adolescents, $46.25 \%$ of them rated their health as good, $32.50 \%$ as very good, $16.25 \%$ as fair, and $5 \%$ as excellent. Most of the adolescents' parents rated their children's health as good (42.50\%), $31.25 \%$ as very good, $20 \%$ as fair, and $6.25 \%$ as excellent. It should be noted that none of the respondents rated their health as poor.

In relation to the questionnaire, in the group of children, the total mean score was 77.22, with a median of 81.65 and a standard deviation of 14.38 . The majority of children $(61.02 \%)$ had a very high quality of life (higher than or equal to 75 points) because, according to the scale's author, the higher the total score, the higher the children's quality of life. Only $3.39 \%$ of the children had a quality of life of less than 50 points. In the group of adolescents, the total mean score for quality of life was 80.69 , with a median of 86.55 and a standard deviation of 16.45 . In turn, most of the adolescents (71.25\%) also had a high quality of life, with scores higher than or equal to 75 points and $8.75 \%$ of them scored less than 50 points.

Children's parents had total mean scores of 80.68 , with a median of 86.61 and a standard deviation of 16.79 , and $69.49 \%$ of them had a quality of life score equal to or higher than 75 points, which corresponds to a good quality of life of their children. Only 6.78\% of parents scored less than 50 points for quality of life. In turn, adolescents' parents had total mean scores of 79.82 , with a median of 85.02 and a standard deviation of 17.83 . In this group, $71.25 \%$ of parents considered that their children had a good quality of life (scores higher than or equal to 75 points) and only $8.75 \%$ of them considered that their quality of life was less than 50 points.

\section{Discussion}

The terminology used in the PCQLI proved to be simple and the process of translation and adaptation into European Portuguese showed a high degree of agreement of translated items, despite minor differences between both translated versions, which, after the consensus version, did not correspond to major changes in meaning, but rather to the use of synonyms.

The involvement of different translators and the panel of experts proved to be very important during this process. This study contributed to obtaining a relevant instrument for health research and clinical practice, which justifies the need for future validation studies. In this study, the authors used the same subscales and parameters as the authors of the original scale. In short, this study revealed high levels of quality of life in children and adolescents with CHD, which is consistent 
with the predominance of simple CHD in this sample. These results are in line with those of Ernst et al. (2018) and Niemitz et al. (2017) who found that patients with severe heart disease and greater need for medical care have worse quality of life.

The 5-month data collection period proved insufficient to develop the validation process, as mentioned above. This was a limitation of this study, as well as the lack of analysis of concurrent validity and test-retest reliability, which should be analyzed in future studies.

Considering the specificity of the sample, as well as the nonprobability sampling method, there is no guarantee of the representativeness of the population, thus the analysis, interpretation, and discussion of the results should be done with caution. For these reasons, future studies should develop strategies for controlling these factors, namely the use of probability sampling methods and larger samples. It should be noted that the limited number of studies on this topic in Portugal made it difficult to interpret the perceived quality of life of children and adolescents with CHD in Portugal.

\section{Conclusion}

This study resulted in the first Portuguese version of the PCQLI, which was translated and adapted to assess the quality of life of children with CHD. We hope that this can be the first step in Portuguese research in the area of $\mathrm{CHD}$ and a driving force for future studies.

The results are interesting and promising regarding the use of the Portuguese version of the PCQLI in clinical practice. This questionnaire covers the main dimensions of quality of life and it is a short, easy to complete tool which uses a clear and simple language. The results found for this version confirm the potential of this instrument.

Considering these properties and the size of the sample, the authors decided to use the same subscales and parameters of the original scale's authors.

Further studies should be conducted in Portugal on this topic, including studies aimed at validating the Portuguese version of the PCQLI.

\section{References}

Daudt, N., \& Zielinsky, P. (2013). Late outcomes of congenital heart disease. Translational Pediatrics, 2(3), 8486. doi:10.3978/j.issn.2224-4336.2013.07.04

DISABKIDS. (2004). Translation and validation procedure: Guidelines and documentation form. The DISABKIDS Group Europe. Retrieved from http://kidscreen.diehauptstadt.de/disabkids/master/download_area/translations/Translation_Procedure.pdf

Ernst, M., Marino, B., Cassedy, A., Piazza-Waggoner, C., Franklin, R., Brown, K., \& Wray, J. (2018). Biopsychosocial predictors of quality of life outcomes in pediatric congenital heart disease. Pediatric Cardiology, 39(1), 79-88. doi:10.1007/s00246-017-1730-6

Kaku, S. (2018). "Problemas" cardíacos na criança. Retrieved from http://www.fpcardiologia.pt/problemas-cardiacos-na-crianca/

Marino, B., Shera, D., Wernovsky, G., Tomlinson, R., Aguirre, A., Gallagher, M., ... Shea, J. (2008). The development of the Pediatric Cardiac Quality of Life Inventory: A quality of life measure for children and adolescents with heart disease. Quality Of Life Research: An International Journal of Quality of Life Aspects of Treatment, Care and Rehabilitation, 17(4), 613626. doi:10.1007/s11136-008-9323-8

Marino, B., Tomlinson, R., Wernovsky, G., Drotar, D., Newburger, J., Mahony, L., ... Shea, J. (2010). Validation of the Pediatric Cardiac Quality of Life Inventory. Pediatrics, 126(3), 498-508. doi:10.1542/ peds.2009-2973

Marino, B., Lipkin, P., Newburger, J., Peacock, G., Gerdes, M., Gaynor, J., ... Mahle, W. (2012). Neurodevelopmental outcomes in children with congenital heart disease: Evaluation and management. Circulation, 126(9), 1143-1172. doi:10.1161/ CIR.0b013e318265ee8a

Marino, B., Hottinger, S., Drotar, D., Wray, J., \& Ittenbach, R. (2014). The Pediatric Cardiac Quality of Life Inventory (PCQLI): A brief user's guide. Cincinnati Children's Hospital Medical Center. Retrieved from https://pcqli.com/node/5/download/9c97e791600f96d35ede7b4027b52598.

Marino, B., Cassedy, A., Drotar, D., \& Wray, J. (2016). The Impact of neurodevelopmental and psychosocial outcomes on health-related quality of life in survivors of congenital heart disease. The Journal of Pediatrics, 174, 11 - 22. doi: 10.1016/j.jpeds.2016.03.071

Muner-Hernando, M., Gil-Mira, M., \& Zapardiel, I. (2013). Avances en el diagnóstico prenatal de las cardiopatías congénitas. Ginecología y Obstetricia de Mexico, 81(6), 334-344. 
Niemitz, M., Gunst, D., Hövels-Gürich, H., Hofbeck, M., Kaulitz, R., Galm, C., ... Goldbeck, L. (2017). Predictors of health-related quality of life in children with chronic heart disease. Cardiology in the Young, 27(8), 1455-1464. doi: 10.1017/S1047951117000440

Rajmil, L., López, A., López-Aguilà, S., \& Alonso, J. (2013). Parent-child agreement on health-related quality of life (HRQOL): A longitudinal study. Health and Quality of Life Outcomes, 11(101). Retrieved from http://www. hqlo.com/content/11/1/101.

Setty, H., Patil, S., Ramegowda, R., Vijaykumar, Vijayalakshmi I., \& Manjunath, C. (2017). Comprehensive approach to congenital heart defects. Journal of Cardiovascular Disease Research, 8(1), 1-5. doi:10.5530/ jcdr.2017.1.1

Sousa, P., \& Cruz, S. (2009). Estratégias recreativas no internamento de pediatria: Intervençóes que promovem a qualidade de vida. In C. Sequeira, C. Santos, E. Borges, M. Abreu, \& M. Sousa, Saúde e qualidade de vida: Estado da arte (pp. 63-67). Porto, Portugal: Núcleo de Investigação em Saúde e Qualidade de Vida.

Vilelas, J. (2009). Investigação: O processo de construção do conhecimento. Lisboa, Portugal: Edições Sílabo.

World Health Organization. (2014). WHO Quality of Life-BREF (WHOQOL-BREF). World Health Organization Website Retrieved from http://www.who.int/ substance_abuse/research_tools/whoqolbref/en/ 
